\title{
EL PECADO DE LOS PADRES: CONSTRUCCIÓN DE LA IDENTIDAD CONVERSA EN CASTILLA A PARTIR DE LOS DISCURSOS SOBRE LIMPIEZA DE SANGRE*
}

\author{
por \\ JUAN HERNÁNDEZ FRANCO \\ Universidad de Murcia
}

RESUMEN: En este articulo se trata sobre un concepto al que diversas ciencias sociales están prestando atención en los últimos años, como es el de identidad; es decir, la representación que de sí mismo bace y proporciona a la sociedad un grupo a partir de una selección interesada de su memoria bistórica. Pero esta representación, cuando existe un conflicto social entre grupos, como ocurre en Castilla durante los siglos XV al XVII entre cristianos viejos y nuevos, es efectuada recurriendo al principio de casta -adscrita a la sangre-por parte de los primeros, con el fin de desligitimar las aspiraciones sociales de los segundos. Y ese retrato adverso lo fabrican los cabecillas de la inteligencia cristiano vieja a partir del momento que judios convertidos, es decir cristianos nuevos y por lo tanto miembros de pleno derecho de la sociedad estamental, quieren conseguir bonores basta esos momentos reservados a los cristianos viejos, en especial a sus elites. Éstos, contando con frecuencia con el apoyo social de los grupos más populares, levantan barreras legales para impedir el acceso de sus rivales al mundo de los privilegios.

Palabras clave: Pureza de sangre. Identidad. Sociedad. Familia. España. Siglos XV-XVII.

ABSTRACT: The subject of this article is one which has been the focus of attention of various social sciences in recent years: identity, in other words the representation which a group makes of itself and presents to society, based on an edited selection of its bistorical memory. When there is social conflict among groups, as happened in Castile during the fifteenth and sixteenth centuries between old and new Christians, this rep-

* Este trabajo forma parte del proyecto de investigación BHA 2002-00901, financiado por el Ministerio de Ciencia y Tecnología.

Asimismo deseamos dejar constancia de nuestro agradecimiento al Dr. James Casey y a la Dra. Rosa Manchón Ruíz por las oportunas y estimables sugerencias que han efectuado al presente artículo.

Hispania, LXIV/2, núm. 217 (2004) 515-542 
resentation was achieved when the former resorted to the principle of caste - connected to blood lines - with the aim of de-legitimising the social aspirations of the latter. This negative portrait was fabricated by the leading intelligentsia of old Christianity from the moment when converted Jews (in other words new Christians, enjoying as such full rights within established society) desired to achieve bonours bitherto reserved for old Christians, and more especially for their elite. These old Christians, often enjoying the social support of the more popular groups, raised legal barriers to prevent their rivals from acceding to the world of privileges.

KEY WORDS: - Purity of blood. Identity. Society. Family. Spain. Early Modern period.

"Los antedichos (descendientes de judíos)... son afligidos por el pecado de deicidio que sus padres cometieron»

Fray Domingo de Valtanás: Apología sobre ciertas materias morales en que hay opinión, Sevilla, 1556.

"La qual ynhavilidad les viene por el delito que cometieron del qual sus deszendientes son partizipantes quanto a la pena»

Respuesta del Reverendísimo Arzobispo de Toledo al requerimiento que se le hizo de parte de los ylustres Arcedianos de Guadalajara y de Talavera hijos del muy ylustre Duque del Infantado».

Nos recuerda J. Casey algo tan sencillo, pero tan verídico y extendido en la sociedad tradicional, como es que el individuo se encuentra atado a un rango, a una casta, a una ocupación, etc., que en gran medida es hereditaria ${ }^{1}$. Así pues, nos está señalando el carácter vinculante de los antepasados. Resultan tan determinantes en tantas ocasiones, que anulan los esfuerzos de las personas para desarrollar su propia trayectoria dentro de la sociedad al margen de su origen. La semilla, la raíz, la cuna, la sangre, la virtud heredada, términos utilizados por los tratadistas castellanos de la Baja Edad Media y de la Edad Moderna, nos están indicando que es el principio lo que adscribe. Pero no solo a alguno de los ordenes de la sociedad estamental. También a otra categoría social que tiene cabida dentro de la ultima y que se aproxima al concepto de casta, entendida como una comunidad que desarrolla una forma de vida que viene determinada, fundamentalmente, por unos ascendientes que tienen en común un honor superior, por lo general relacionado con la etnia, la religión, la profesión y las relaciones sociales.

\footnotetext{
CASEY, James: Historia de la familia, Madrid, 1990, p. 42.
} 
El origen y parte de la memoria creada por los antepasados, es decir una porción de su existir, se utiliza para producir identidades sociales; o lo que es lo mismo, la representación que de sí mismo hace y proporciona a la sociedad un grupo en un momento dado de la historia ${ }^{2}$. Dicha identidad tiene como fin: legitimar una posición social, hacerla duradera y conseguir una cuota de distinción u honor dentro de un sistema social ${ }^{3}$. Pero no todas las identidades tienen el mismo peso dentro de la organización de una sociedad. Es común opinión que las elites o grupos dominantes están en condición de imponer su imagen, mientras que restan importancia a la de otros grupos, o lo que aun es peor, se la construyen a partir de la manipulación de la memoria colectiva de sus antepasados, pues persiguen el fin de deslegitimarlos socialmente.

Precisamente ese moldeado peyorativo y socialmente deslegitimante de la identidad de un grupo social a partir de sus antepasados y su existencia, y que resume bien la idea de linaje "dañino", es efectuado por otros, situados en una posición social de dominio, para fijar el lugar de los «conversos de judíos» en Castilla a finales del Medievo y primeros siglos de la Modernidad. En concreto, esos otros que quieren cerrarles el paso a la sociedad del honor, es un grupo con arraigo dentro de la sociedad de ordenes, que se atribuye una cierta situación de prevalencia -a la limpieza se la considera una nobleza «menor» pero imprescindible- a consecuencia de lo que constituye su nosotros, representado por una limpia raíz cultural, que además siempre ha sido fiel a una memoria, a una existencia cristiana, y que a la postre se convierte en un modelo identitario predominante.

Una de las piezas ideológicas que mejor recoge esta contrapuesta y desigual realidad de identidades son, sin lugar a dudas, los discursos y memoriales que hacen apología a favor de la limpieza de sangre. Bastantes de ellos se efectúan con el propósito de discriminar al converso dentro del orden social estamental ${ }^{4}$. Por eso, sus autores, partidarios de la superioridad social de los cristianos viejos, construyen la identidad del contrario situándolo como herederos de la cultura hebrea, y, a su vez, remarcando actitudes críticas y pervertidas respecto al ordenamiento social en el que han ingresado.

Ahora bien, la construcción de identidades y las razones o causas de su necesidad y existencia, no es posible entenderla desde la óptica que nos ofrecen los cristianos viejos ${ }^{5}$ sin la correspondiente integración dentro de un período

2 Un adecuado y amplio tratamiento sobre memoria e identidad, efectuado a través del estado de la cuestión en diversas ciencias sociales, lo encontramos en ROSA RIVERO, Alberto, BELLELI, Guglielmo y BAKHURST, Daniel (Eds.): Memoria colectiva e identidad nacional, Madrid, 2000, p. 41-82.

3 BOURDIEU, Pierre: El sentido práctico, Madrid, 1991, pp. 233-235.

4 Esta tendencia discriminatoria de los estatutos ha sido magistralmente desarrollada en sus obras, respectivamente, por SiCROFF, Albert: Los estatutos de limpieza de sangre, Madrid, 1986; y por Domínguez ORTíz, Antonio: La clase social de los conversos en Castilla en la Edad Moderna, Granada, ,edición facsímil, 1991.

5 La propia construcción de la identidad conversa, más allá de una mera afirmación de principios religiosos y vista como un conflicto o lucha con el cristiano viejo, sujeta además a las variantes que suponen la expulsión de los judíos y la intolerancia religiosa, ha sido tratada con gran detalle 
temporal y sus correspondientes valores y hechos sociales, que con frecuencia resultan inductores o percutores de la identidad que se quiere crear, especialmente, como cuando en el caso que nos ocupa, es una contraidentidad. De ahí que previamente al análisis de ésta, debamos referirnos a una época, siglos XV, XVI y parte del XVII, en la que existían depósitos ideológicos que reconocían carácter determinante al origen; en la que persistían rasgos castizos, debido a la coexistencia en tiempos anteriores de tres culturas que tenían como matriz el «hecho religioso»; y en la que hubo (por lo menos hasta la segunda mitad del siglo XVI) posibilidades de movilidad social ascendente para familias que adoptaran el modo de vida dominante, es decir el nobiliario y su correspondiente ethos. Igualmente, y aunque aquí no los trataremos, pero no podemos olvidarlos, pues son hechos que atraviesan todo el período de tiempo citado, tenemos por un lado una profunda revisión del hecho religioso católico, la conocida y necesaria Contrarreforma, que como en su momento señalaron M. Bataillon y $\mathrm{M}$. Batllori, entre las décadas segunda y sexta del quinientos, es decir antes de la fijación dogmática efectuada en el Concilio de Trento (1545-1563), no determina unos límites fijos entre ortodoxia y heterodoxia; este hecho fue perjudicial para el converso, pues como sucesor del judío se le adjudican frecuentemente posturas próximas a la apostasía, lo cual influye, como ha escrito E. Benito Ruano en un «soterrado y latente estado de < guerra civil de religión $>{ }^{6}$. Y por otro, las medidas políticas en contra de los judíos (expulsión, conversiones obligatorias.....) y sus consecuencias sobre el converso, así como también las decisiones que sobre estos toman los Monarcas (creación de la Inquisición, perdones generales, edictos de gracia...) y las Cortes (Memoriales).

\section{LOS DEPÓSITOS DOCTRINALES ${ }^{7}$}

El papel desempeñado por la sangre dentro del sistema social, dentro del sistema social estamental, necesariamente hay que buscarlo en depósitos doc-

\footnotetext{
por BODIAN, Mirian: «<Men of the Nation>: The shaping of converso identity in Early Modern Europe», Past and Present (Londres), 143 (1994), pp. 48-76; aunque su trabajo dedica mayor atención a los conversos portugueses, mucho más cercanos a la ley mosaica que los castellanos. Por su parte KAPLAN, Yosef: Judios nuevos en Amsterdam. Estudios sobre la bistoria social e intelectual del judaísmo sefardí en el siglo XVII, Barcelona, 1996, pp. 56-77, pone de manifiesto que la autoidentidad del sefardí que se traslada a Amsterdam encuentra su fundamento en una tradición cultural con rasgos íbero-cristianos —entre los que se encontraba paradójicamente la «nobleza y pureza de sangre»-, que no siempre concuerda con la tradición rabínica.

6 Benito RuANO, Eloy: Los orígenes del problema converso, Barcelona, 1976, p. 35.

7 Así titulaba uno de los apartados de su trabajo el profesor RoDríGuez SÁNCHEZ, Angel: «Familia y vida cotidiana en la España de Felipe II», en MArTínEz Ruíz, Enrique (ed.): Madrid, Felipe II y las ciudades de la Monarquía, Vol. III, Madrid, 2000, pp. 18-26. Destaca Angel Rodríguez Sánchez la importancia que tienen las composiciones teóricas como medio para organizar realidades sociales como casa, linaje y familia, al menos en el mundo privilegiado
} 
trinales de carácter o naturaleza general, y a partir de los mismos, dejar abiertos caminos que nos permitan conocer como fueron empleados por parte de aquellos que enarbolan la pureza de la sangre para excluir, o bien para limitar la presencia de individuos pertenecientes a linajes manchados en instituciones que eran consideradas distinguidas y que batallaron por no perder la cuota de honor que tenían reconocida dentro de la organización social.

Posiblemente existan otros depósitos doctrinales. Sin embargo, dos de los que los tratadistas obtuvieron argumentos fueron, por un lado y como no podía ser de otra manera, la escolástica y su concepto de sociedad unitaria y armónica; y de otro, que a su vez también conectaba con el anterior, de una cultura nobiliaria que define la posición que se ocupa en la sociedad - es decir justifica la desigualdad social - a partir del nacimiento y del existir o vivir como grupo.

En el origen de aquella sociedad orgánica y estamental, construida a partir de una concepción y doctrina cristiana del mundo, siempre estuvo Dios. Dios para la escolástica era la causa primera, el fundamento primero. La naturaleza, la creación, la propia organización social eran causas segundas o subordinadas a la primera, es decir causas ministras; y, en concreto, la sangre o la herencia como parte de esa naturaleza no podía quedar fuera del orden divino. Para la escolástica la sangre permitía conservar, de una generación a otra, la ordenación jerárquica de la sociedad que Dios había introducido desde el principio del mundo ${ }^{8}$. A partir de este principio, es comprensible el papel determinante y reproductor de conductas de la sangre, de la descendencia, del linaje, y el deseo de remontarse a través de las genealogías a los antecesores más próximos a la creación del mundo por parte de Dios, quien entonces hizo una gradación de ordenes y situó en la cabeza del mismo a la nobleza.

Ciertamente la escolástica, más especulativa que práctica, no trató de la sangre y la herencia como problemas teóricos principales ${ }^{9}$. No obstante y con un sentido de uso social práctico, los tratadistas que enarbolan la sangre limpia de mancha étnico-religiosa como una calidad social, como un honor, convierten su ascendencia, su herencia, en un determinante positivo, ya que «ellós y sus antepasados continuamente conservaron nuestra santa fe, y la guardaron pura y limpiamente»; y como un determinante negativo, como una afrenta, la sangre y los antepasados de los espurios, pues le hacía reasumir «las costumbres de sus progenitores». ${ }^{10} \mathrm{Y}$ precisamente los tratadistas —en concreto Juan Martí-

\footnotetext{
8 Maravall, José Antonio: Poder, honor y elites en el siglo XVII, Madrid, 1984, pp. 45-47; y Teatro y Literatura en la sociedad barroca, Barcelona, 1990, p. 41.

9 SIERRA BRAVo, Restituto: El pensamiento social y económico de la Escolástica, Madrid, 1975, p. 57.

10 Biblioteca Nacional de España (en adelante BNE), Manuscrito (Ms.) 6.170, «Libro de las causas que el Reverendísimo Arzobispo de Toledo Don Juan Martínez Silizeo y su Cavildo movieron a hazer el estatuto que el año pasado hizieron en el qual asimismo se ponen las causas que a los contraditores del dicho estatuto movieron a contradezir, con las cuales y otras muchas que pudieron alegar se pone la respuesta que el Reverendisimo Arzobispo y su Cavildo dieron; presentose el dicho libro ante el muy alto Consejo de Su Majestad el Emperador nuestro señor». Parte segunda: «Algu-
} 
nez Siliceo, Arzobispo de Toledo ${ }^{11}$ - aportan pruebas a favor de su teoría espigándolas entre las «autoridades escolásticas»: Sagradas Escrituras (Números, Deuteronomio, Salmos, Evangelios de San Mateo, de San Marcos y de San Lucas, Cartas de Pablo a Tito y a Timoteo), fuentes eclesiásticas (Concilios Provinciales), Santos Padres (San Jerónimo, San Agustín, San Juan Crisóstomo), fuentes jurídicas (Digesto Viejo), y autores escolásticos y a la vez antihebreos como Alonso del Madrigal, más conocido por «el Tostado» ${ }^{12}$. Con su empleo pusieron de relieve que los conversos «deszienden de judíos» y que la forma de vida del linaje está

nas autoridades así de las Sagrada Scriptura como de los sacros cánones y algunas sentencias de doctores y otras razones por las quales evidentemente se puede colegir y ynferir el dicho statuto si es santo y conforme a razón".

11 Indiscutiblemente la personalidad de Juan Martínez Siliceo (1486-1557) merece que hagamos una breve reseña biográfica-ideológica del mismo. No era un hombre de alcurnia como otros que ocupan la mitra de Toledo. Todo lo contrario. Era hijo de un modesto labrador castellano que buscó desde muy temprana edad horizontes más amplios. Llego a estudiar en la Sorbona con provecho, y de hecho enseñó en este importantísimo centro universitario. A su regreso a Castilla ingresó en el Colegio Mayor de San Bartolomé de la Universidad de Salamanca, donde se exigía desde el siglo anterior limpieza de sangre para acceder al mismo. Señala uno de los mejores conocedores del personaje, A. Domínguez Ortiz, que es posible que en este centro se forjaran sus ideales sobre la desconfianza hacia los conversos y la idea de que se les debía apartar de los cargos eclesiásticos; además, fricciones con altos cargos del cabildo eclesiástico que presidía, como es el caso del deán Diego de Castilla, converso y descendiente ilegítimo de reyes de Castilla, le llevaron a valorar más la limpieza de sangre que la alcurnia nobiliaria.

Con anterioridad a su acceso al Arzobispado de Toledo, ocupa cargos importantes en la Corte, pues el Emperador Carlos V lo nombra preceptor del príncipe Felipe, y a pesar de que el Cesar no estuvo conforme con el aprendizaje que el maestro había llevado a cabo con su hijo, al que contentaba demasiado (como nos dice FernáNDez Álvarez, Manuel: Carlos V: el Cesar y el hombre, Madrid, 1999, p. 369), lo propondrá para el cargo eclesiástico más distinguido y reputado de Castilla: el Arzobispado de Toledo, la segunda Iglesia de la Cristiandad tras el Vaticano ẹn opinión de sus arzobispos. Fue desde la dirección de esta destacada institución, desde la que lleva a cabo el liderazgo del "partido cristianoviejo». Los puntos básicos del mismo (HERNÁNDEZ FRANCO, Juan: «El partido de los cristianos viejos establece estatuto de limpieza de sangre el año 1544 en el Cabildo Catedral de Murcia», Murgetana (Murcia), 103 (2000), pp. 57-70) son los siguientes: $1^{\circ}$ ) Animadversión hacia el cristiano nuevo, ya que allana la paz y tranquilidad que necesita ese cuerpo perfecto que es la República Cristiana. $2^{\circ}$ ) Pueden demostrar que su cristianismo es inmemorial. $3^{\circ}$ ) Poseen una fe auténtica. $4^{\circ}$ ) Anteponen la unidad de la Iglesia a cualquier propuesta herética. $5^{\circ}$ ) Eran leales a la Monarquía. Con ese programa, el año 1548, obtuvieron el consentimiento del Emperador para el Estatuto de limpieza que querían establecer en la catedral de Toledo, y con posterioridad, tras ser ratificado el estatuto por el Papa Paulo IV el año 1555, Siliceo logrará que lo sancione su antiguo discípulo, el rey Felipe II el año 1556, que ya desde el primer año de su reinado hizo de la limpieza de sangre una cuestión importantísima a la hora de encargar u otorgar funciones (Vease al respecto DomínGUEZ ORTIZ, Antonio: Los judeoconversos en la España Moderna, Madrid, 1992, pp. 143-147; y HERNÁNDEZ FrANCO, Juan: «El <consentimiento $>$ del Emperador a los estatutos de limpieza de sangre y el comienzo del viraje hacia la Monarquía Católica», en Castellano CASTEllano, Juan Luis y SÁNCHEZ-MONTES, Francisco (eds.): Carlos V. Europeismo y Universalidad, Vol. IV, Madrid, 2001, pp. 365-386).

12 BNE, Ms. 6.170: «Libro de las causas....». Parte segunda: «Algunas autoridades así de las Sagrada Scriptura como de los sacros cánones y algunas sentencias de doctores y otras razones por las quales evidentemente se puede colegir y ynferir el dicho statuto si es santo y conforme a razón».

Hispania, LXIV/2, núm. 217 (2004) 515-542 
repleta de «muchas malas propiedades». Por ese motivo ponen en peligro los fundamentos de la sociedad, su armonía religiosa y política.

El segundo depósito del que se extraen argumentos sobre el carácter determinante de la sangre, lo encontramos en la cultura nobiliaria y en sus teorías ${ }^{13}$. Bastantes de sus tratadistas, de forma reverencial y encumbradora, enarbolaban el origen, la cuna, los antepasados y su herencia imborrable, como criterio determinante para situar a los hombres dentro del orden social ${ }^{14}$; aunque la práctica va, a veces, por otros derroteros ${ }^{15}$

Ciertamente solo queremos señalar la existencia de un paralelismo entre los tratadistas nobiliarios, más tradicionales ${ }^{16}$, aquellos que piensan que el origen

13 Posiblemente la Comedia del Siglo de Oro también tenga influencia en la cristalización de una cultura que reconoce una determinada posición social a partir de la sangre. Desde Lope de Vega hasta Calderón, señala MARAVALL, José Antonio: Teatro y Literatura..., p. 41, la herencia aparece como fundamento del orden social.

14 Entre los trabajos más recientes que tratan esta cuestión, destacan los de CARRASCO MARTÍNEZ, Alfredo: «Herencia y virtud. Interpretaciones e imágenes de lo nobiliario en la segunda mitad del siglo XVI", en La Corona de Castilla, Vol. IV de Las sociedades ibéricas y el mar a finales del siglo XVI , Madrid, 1998, pp. 231-271; y «Las noblezas de los reinos hispanos. Modos de interpretación y conflictos en la segunda mitad del siglo XVI», en BELENGUER CEBRIÁ, Enric (ed.): Felipe II y el Mediterráneo, Vol. II, Madrid, 1999, pp. 18-38; y ÁlvareZ-Ossorio AlvariÑo, Antonio: «El arte de medrar en la Corte: rey, nobleza y el código del honor», en CHACÓN JIMÉNEZ, Francisco y HeRnÁNDEZ FranCo, Juan (eds): Familias, poderosos y oligarquías, Murcia, 2001, pp. 39-60.

15 LAMBERT-GoRGES, Martine y Postigo, Elena «Santiago et la porte fermees: les candidatures malhereuses a l'habit", en Les societes fermees dans le Monde Iberique (XVI-XVIIIe s.), París, 1986, pp. 138-167, muestran claramente como a pesar del cierre de la Orden Militar de Santiago a todo aquel que no fuese noble y cristiano viejo (lo último a partir de 1575), fueron muy pocos los candidatos reprobados por su origen converso.

$Y$ una muestra evidente de que esta sangre manchada no es un obstáculo social insalvable, la encontramos en la familia de la principal figura de la mística castellana, Teresa de Jesús. La familia materna, los Cepeda, eran cristianos viejos. Pero la paterna , los Sánchez de Toledo eran comerciantes, conversos y el abuelo había sido penitenciado por la Inquisición. Intentaron ocultar su pasado recurriendo a estrategias muy empleadas por parte del nuevo cristiano, como cambiar de apellido, la mudanza de localidad, o la compra de testigos que mejorasen el origen del linaje. Tales estrategias permitieron al padre de Santa Teresa adquirir un título de hidalguía y casar a sus descendientes con hijos de familias respetables.

Este ejemplo demuestra la capacidad de maniobra que existía dentro de la sociedad castellana, y de qué forma los orígenes espurios no impedían alcanzar, cuando menos, el grado más bajo de la nobleza: la hidalguía, o bien "colocarse» en alguna institución de prestigio que tuviere estatuto de limpieza de sangre, como ocurre en cabildos catedralicios, ordenes religiosas, colegios mayores, regimientos.....(Un buen resumen de lo expuesto puede encontrarse en DomínGUEZ ORTIZ, Antonio: Los judeoconversos en la España..., pp. 261-264).

16 Eso no es óbice para que en la segunda mitad del siglo XVI en Europa Occidental, como prueban los trabajos de SCHALK, Ellery: E l'epee et la sang. Une histoire du concept de Noblesse (vers 1500-vers 1600), Seyssel, 1996, passim; y HARDING, Robert R.: Anatomy of a Power Elite: The Provincial Governors in Early Modern France, New Haven and London, 1978, y en particular en Castilla (CARRASCO MARTíneZ, Alfredo: «Herencia y virtud...", pp. 256-259) haga su aparición un «nuevo caballero", un nuevo modelo de noble, producto y consecuencia de los cambios que están sucediendo, especialmente en la cultura política. Ahora, los tratadistas sin llegar a desdeñar la antiguedad 
otorga virtudes inmemoriales, o lo que es lo mismo, que la virtú la otorga la herencia y la raza, y los de la pureza de sangre. Pero un paralelismo mimético, ya que los que exaltaban la cuna limpia (que tan solo privaba de estigma o defecto) como principio de distinción social, no intentaron en la mayoría de las ocasiones poner esta cualidad por delante de la cuna noble ${ }^{17}$. Pretendieron que de la misma manera que existía una teórica «ley de la nobleza», que estaba fundada en la «nobleza de linaje y sangre» como escribió el doctor Diego García de Palacio casi a finales del siglo XVI ${ }^{18}$, también se reconociera la existencia de una supuesta «ley de la limpieza». La misma debía conceder un nivel de honor o estima a los que procediesen de linajes limpios, más la ventaja social a aquellos que tuviesen la cualidad, de disponer de la reserva - no lo olvidemos en un período de movilidad social ascendente- de oficios en instituciones de prestigio. Y así debía ser, pues la calidad de su linaje, sin el defecto de la sangre espuria, o cuando menos sin fama o rumor de tal mancha, convertía a los cristianos viejos, según B. Ximénez Patón (en su obra Discurso a favor del Santo y Loable Estatuto de la limpieza) en «beneméritos, por su antigua limpieza» ${ }^{19}$.

Estamos, pues, ante un embelesamiento en el «nosotros», ante la exaltación de unos valores que aportan los ascendientes y que precisamente son de los que carecen los otros ${ }^{20}$, debido al defecto imborrable que les aporta la sangre de sus

de la sangre, valoran y exaltan una virtud individual que se adquiere a través del conocimiento de las letras y de las ciencias, de la riqueza, y sobre todo mediante el servicio militar y administrativo a la Corona, o incluso mediante unas buenas relaciones cortesanas

17 «Nuestra España tiene en mayor importancia la Nobleza e Hidalguía que no la Limpieza (porque aquella es Nobleza positiba, que da honra y lugar a la persona y la Limpieza no es Nobleza, sino privación de ignomia, de que gozan los más humildes y bajos)». Tal afirmación se encuentra en el «Discurso de un Inquisidor, hecho en tiempos de Phelipe IV sobre los estatutos de limpieza de sangre de España, y si conviene al servicio de Dios, del Rey y Reino moderarlos» (Citado por DoMÍNGUEZ ORTIZ, Antonio: La clase social, p. 234).

18 García De Palacio, Diego: Diálogos militares, Madrid, edición facsímil, 1944, folio 37 v.

19 XImÉnez Patón, Bartolomé: Discurso en favor del Santo y Loable estatuto de la limpieza, Granada, 1638, folio 4 v. y 7 v.

El autor del Discurso es otro ejemplo más de hombre en el que se produce una lenta evolución desde el último Humanismo, fundamentalmente preocupado en el conocimiento del latín y de la retórica, hacia el ensimismamiento en torno a valores patrios, a la preocupación por la pureza de la religión, y a la sujeción al rigor inquisitorial. De hecho, y a pesar de la pluralidad de temas sobre los que trabaja (moda y vestidos, uso del tabaco, historias locales, poesía religiosa, comentarios sobre Marcial, obras de gramática y retórica), concluirá siendo un hombre del barroco. Un hombre que busca la seguridad ante la tormenta que puede venírsele encima por manifestar ideas no conservadoras. Mas aún en la época en la que escribe el Discurso, en la que según J. H. Elliott, la Monarquía está ya inmersa en la etapa de "pérdida de reputación». Para hacerla menos evidente, la intelectualidad ha de apostar y participar en una campaña en la que la religión y la tradición sean valores refugio, y las instituciones puedan controlar con vigor la entrada de judíos, moros, y luteranos, hombres pertenecientes a linajes a los que el autor dice que hay que "cerrarles la puerta y darle con ella en la cara».

20 Nos parece de enorme interés las consideraciones efectuadas sobre la creación de identidades (tanto la propia como la del contrario) por AZURMENDI, Mikel: $Y$ se limpie aquella tierra. Limpieza étnica y de sangre en el País Vasco (siglos XVI-XVIII) , Madrid, 2001. 
antepasados. Por eso, resulta frecuente, que la prueba de la calidad de la sangre como criterio para ocupar una determinada posición social, contenga cuando se argumenta en sentido excluyente, los deméritos y prejuicios que aporta un origen al que se convierte en eterno e imborrable. Tal argumentación ya había sido enunciada en la propia tratadística nobiliaria por parte de Juan Arce de Otálora ${ }^{21}$, para quien los conversos a causa de la «sangre infectada» de sus antepasados quedan privados de los «honores» ${ }^{22}$. Y será ampliamente desarrollada por ardientes defensores del linaje puro como el inquisidor Escobar del Corro. Éste, en su Tractatus bipartitus de puritate et nobilitate probanda (1637), es posiblemente quien mejor recoge la relación que existe entre la condición de la sangre y el status social que habilita para desempeñar empleos con honor o distinción. Señalará que la infamia, que la carencia de cualidades para desempeñar estos oficios está de forma permanente en la sangre, y que es la sangre la que mancilla, la que dirige, la que gobierna al converso, inclinándolo desde el mismo momento de su procreación hacia la conducta y costumbres de sus antepasados:

«quod respicit infectum sanguinem velat iure haereditario translatum in filios in ipsa conceptione» 23 .

\section{2. «HAY EN ESPAÑA DOS LINAJES DE HOMBRES, UNOS CRISTIANOS VIEJOS QUE NI ELLOS NI SUS ANTEPASADOS TROPEZARON EN LA FEE Y OTROS CONFESOS DESZENDIENTES DE HEREJES Y HOMBRES ENEMIGOS DE NUESTRA FEE» ${ }^{24}$}

Esta opinión, sin duda representativa, pues la rubrica Juan Martínez Silíceo, líder del grupo cristiano viejo en la Castilla del siglo $\mathrm{XVI}^{25}$, permite percibir que

21 El jurista Juan Arce de Otálora nace en fecha desconocida y muere en Valladolid a finales de 1561 o principios de 1562. Fue un destacado jurisconsulto y desempeñó cargos en las Chancillerías de Granada y Valladolid. Perteneciente a una familia hidalga y señalado como humanista y profundamente católico por algunos de sus estudiosos, destaca por encima de todo por ser uno de los principales autores del derecho nobiliario. En concreto, su fama le vendrá por su obra De nobilitatis et inmunitatis Hispaniae causis, publicada por vez primera el año 1553, y reeditada posteriormente, por lo menos, en los años 1570,1584 (Venecia) y 1613. Consiste en un tratado de hidalguía, en el que se presenta al estamento como un grupo social distinguido por sus innumerables virtudes y privilegios, que conserva y transmite de padres a hijos, precisamente a través de la sangre y de la estirpe. Véase al respecto LoRCA MARTín De VILlodrés, María Isabel: El jurista Juan de Arce de Otálora (siglo XVI). Pensamiento y obra, Madrid, 1997.

22 Mechoulan, Henry: La sang de l'autre ou l'bonneur de Dieu. Indiers, juifs et morisques au Siècle d'Or, París, 1979, p. 119.

23 Citado por SiCROFF, Albert: Los estatutos de limpieza...., pp. 262-263.

24 BNE. Ms. 6170. "Libro de las causas...», y, en concreto, "Respuesta que el Reverendísimo Arzobispo de Toledo y su Cavildo dieron a el scripto de las 10 causas que los contradictores del statuto dieron». 
los castellanos en lo que respecta a su organización social, admitían y utilizaban la división en castas - aunque jurídicamente no tuviesen valor-, pero ocurrió que una parte importante las admitieron y las consensuaron como elemento de identificación social. Por tanto, parece muy correcta la opinión de quienes sostienen la existencia de rasgos castizos dentro de la sociedad estamental castellana. Empezando, lógicamente, por Américo Castro. Señaló que las creencias que convivieron obligatoriamente sobre la morada vital hispánica fueron, en realidad, la base y el horizonte de vida de quienes las siguieron; y que a pesar de desaparecer la tolerancia que hizo posible su coexistencia a finales del siglo XV, tras la unificación religiosa que llevan a cabo los Reyes Católicos, las castas perviven y constituyen un entramado fundamental de lo hispano hasta el siglo XVIII ${ }^{26}$.

Sin lugar a dudas, don Américo enfatizó -posiblemente en demasía- en las creencias, ya que a partir de las mismas se podía obtener dentro de la comunidad algo tan importante como era una posición, atrevámosnos a decir que más o menos distinguida ${ }^{27}$, pues diferencia entre puros e impuros a partir de la forma de practicar la religión. Sus importantes trabajos se vieron completados dentro de la historiografía castellana por los del profesor Juan Ignacio Gutiérrez Nieto, que tras señalar que en el siglo XV se produce un debilitamiento de la estructura castiza - debido al retroceso de las castas minoritarias-, pone de manifiesto que en el siglo siguiente se revitalizan las representaciones sociales de signo encastizador. Explica esta revitalización, indicando que elementos que integran el sistema de castas, tan alejados por tanto de la virtú personal, son puestos al servicio de la estructura estamental, ya que quienes están al frente de la organización social, es decir la nobleza tradicional, hace uso de esos elementos para protegerse y dar continuidad a su situación de dominio y a los valores en los que se apoya ${ }^{28}$. Era la mejor manera para resguardarse frente a la forma de vida o cultura de los otros, frente a su forma de religiosidad — pese a que interioriza en el cristianismo-, frente a unas huellas sanguíneas diferentes, o frente a unas formas intelectuales y estéticas críticas con el rancio modelo intelectual del castellano viejo, como lo demuestra la literatura de autores conversos, desde Fernando de Rojas hasta Mateo Alemán, pasando lógicamente por Fray Luis de León ${ }^{29}$. Solo así quienes tienen la virtú nobiliaria que otorga el linaje remoto y glorioso, o la virtú de la

25 Sobre las características del grupo puede verse HERNÁNDEZ FRANCO, Juan: «El partido de los cristianos viejos...», pp. 57-70.

26 CASTRO, Américo: La realidad histórica de España, México, 1976, pp. 43-61, y Sobre el nombre $y$ el quién de los españoles, Madrid, 1985, pp. 176-179.

27 Precisamente ha sido DumONT, Louis: Homo bierarchicus: essai sur le système des castes, París, 1966, quien mejor ha puesto de manifiesto la relación existente entre las jerarquías efectivas dentro de las castas y el honor o categoría social que se atribuye a estas. Hasta el extremo de convertirse en un instrumento práctico de estratificación o reserva social importante y distinguido; es decir lo que hoy llamaríamos «capital social».

28 GUTIERREZ NieTo, Juan Ignacio: «La estructura castizo-estamental de la sociedad castellana del siglo XVI», Hispania (Madrid), 125 (1973), pp. 519-562.

29 AlCalÁ, Angel: «El mundo de los conversos en la literatura y en la mística del Siglo de Oro», Manuscrits (Barcelona), 10 (1992), pp. 91-118.

Hispania, LXIV/2, núm. 217 (2004) 515-542 
pureza que otorga un pasado sin descendientes judíos, moros, indios, negros, o simplemente protestantes, no se verán socialmente desplazados o paralizados por los que enfatizan en el mérito personal.

No podían, pues, aunque nos encontráramos en plena fase renacentista y se valoran los méritos individuales, situarse al mismo nivel de calidad y honor social que los que permanentemente habían pertenecido a la sociedad cristiana, a la República Cristiana; es decir el cristiano de siempre y especialmente a los más virtuosos de ellos en razón de su sangre noble - tal como se señalan en algunos estatutos de limpieza de sangre-, que consideran estimados o respetados, en una palabra hombre de honor a «las personas hijosdalgas de sangre» ${ }^{30}$.

Por tanto, hasta el momento, vemos como se ha insistido principalmente en dos rasgos como fundamentales de las castas que funcionan dentro de la sociedad estamental castellana, lo que permite encontrar dentro de ella grupos definibles por el grado de pureza religiosa y por la práctica de determinadas funciones o profesiones, lo que a su vez les induce a desarrollar una determinada forma de vida. Sin embargo se pueden añadir otros rasgos como el tipo étnico ${ }^{31}$, es decir, la raza; como la tendencia a comportamientos endógamos; o bien, y en éste pretendemos hacer especial hincapié, la vinculación a un linaje, a una determinante línea de descendencia unilineal, a unos antepasados, que, a la postre, identifican de forma imperecedera - mucho mas allá de las conductas y de las formas de religiosidad-.

Buen ejemplo de ello se encuentra en las ordenanzas estatutarias. Pero Sarmiento, líder del movimiento cristiano viejo en la revuelta que se produce en Toledo el año $1449^{32}$, con motivo de la Sentencia-Estatuto que hace promulgar (también de 1449), diferencia entre el cristiano viejo y los «conversos de linaje de judíos» o «descendientes del linaje y ralea de judíos». Por su parte, cien años después y tras haber continuado infiltrándose los cristianos nuevos en las instituciones más prestigiosas, el arzobispo Siliceo y sus partidarios, a la hora de esgrimir argumentos favorables sobre el estatuto que acaban de establecer en el cabildo catedral de Toledo, manifiestan la división castiza que origina el linaje, tal y como se recoge en el título de este apartado. Parece, pues que la casta anula todo el propósito de asimilación que realizaron bastantes familias conversas de Toledo ${ }^{33}$.

30 Maravall, José Antonio: Poder, bonor..., pp. 68-79.

31 La enfatización de la raza, en la étnia relacionada con el linaje, antes que en la conducta religiosa como medio para identificar al converso, es desarrollado en su trabajo por BODIAN, Miriam: «<Men of the Nation > ......., pp. 56-58.

32 Fue un típico problema fiscal el que desató nuevamente en Toledo los disturbios antijudíos. A principios de 1449 el valido de Juan II, Alvaro de Luna, decide imponer a la ciudad de Toledo un empréstito forzoso y extraordinario de un millón de maravedís. Encarga la recaudación al converso Alonso de Cota. Y fue este grupo el que sufrió el descontento de la política fiscal, contestada mediante una revuelta popular que tuvo lugar el 26 de enero del citado año, en la que los cabecillas de la misma responsabilizan de todos los males que padece el regimiento toledano a los cristianos nuevos.

33 Véase como exponente de lo señalado el reciente trabajo de PARELLO, Vicent: Les JudeoConverse: Tolede XVe-XVle siècles: De l'exclusion à l'intégration, Paris, 1999, que incide en una realidad 
En los estudios sobre judaísmo contemporáneo cuando se responde a la cuestión equé es lo que sirve de vínculo y nos permite hablar en términos generales de judíos?, se señala que ante la carencia de un prototipo racial compartido y de una creencia uniforme, lo que da unidad a todos los que se consideran judíos es que se sienten integrantes de la misma y enorme familia; por tanto, la familia desempeña un papel importantísimo en la conservación y reproducción del judaísmo ${ }^{34}$. También Américo Castro y, sobre todo, Julio Caro Baroja destacaron el papel de las relaciones familiares y de los antepasados en la organización de las comunidades judías y posteriormente conversas de Castilla. Hubo una continua preocupación por no perder la memoria de los antepasados, por el linaje, principal referente de su forma de vida. Lo mantuvieron vivo a través de la realización de alargadas genealogías que, en ocasiones, llegaban hasta el propio Abraham; de esta forma no olvidaban quiénes eran y se reconocían primero como pueblo y luego como una comunidad con forma de vida propia, pues la sangre común y el parentesco que proporcionaba el origen les conducía a identificarse con un linaje-nación, en el que no profesaban todos la misma religión. Y ese linaje-nación se sentía, por lo menos hasta el momento de la conversión, orgulloso de la sangre de sus antepasados, una «sangre divinal» como señaló a mediados del siglo XV el obispo - por cierto converso- Lope Barrientos; a partir de la cual y precisamente dándole la vuelta a los argumentos, los cristianos viejos iban a confeccionar la identidad del converso. Así lo puso de manifiesto un fino observador de la realidad, el franciscano Uceda, quien en un tratado contra los estatutos (1588), señala que en la confrontación en pos de las «honras», es decir de los oficios de distinción, a falta de virtud en algunos cristianos viejos para desempeñarlos,

«queréis alcançarlos por el linaje, y como no podéis poner mácula en la persona de vuestro competidor, poneisla en su linaje, y deshazéis a él por hazeros vos»35.

La pureza de la sangre de los antepasados de los conversos fue vista desde otra perspectiva muy diferente por el cristiano viejo, en concreto como «sangre

\footnotetext{
final, como es que los conversos tras cambiar su forma de vida logran integrarse en los escalones más destacados de la sociedad castellano vieja.

Igualmente debe recordarse lo señalado por SiCROFF, Albert: Los estatutos de limpieza...., pp. 61-85, y 96-101, referente a que propuestas de reunificación en la fe, escritos irénicos, prehumanistas y reconciliadores como los de fray Alonso de Oropesa en su Lumen ad revelationem gentium, o la llamada a favor de la unidad de la iglesia del descendiente de conversos y obispo de Burgos, Alonso de Cartagena, en su Defensiorum Unitatis Christianae, a la altura de 1550, no han calado lo suficiente en la sociedad toledana.

34 LANGE, Nicholas de: El judaísmo, Madrid, 2000, pp. 25-28.

35 Tratado donde se ponen algunas razones y fundamentos contra el Statuto que en la Congregacion General de Toledo bizieron los frayles menores el año de mil y quinientos y ochenta y tres donde se ordenó que ningun descendiente de judios, sarrazenos o berejeres (quovis remoto gradu trabat originem) sea reçebido a la Orden. [Editado por PÉREZ FERREIRO, Elvira: El tratado de Uceda contra los Estatutos de limpieza de sangre, Madrid, 2000, pp. 91]
} 
reprobada», según escribía el año 1548 un procurador del Santo Oficio, el bachiller Pedro Ortiz ${ }^{36}$. Y, precisamente, los componentes de este último grupo social para hacer distinguida a su casta dentro de la sociedad estamental y poder ocupar de forma exclusiva y excluyente los empleos con honor, construyen una imagen de la otra casta a partir del comportamiento de su linaje-nación, de su gentilicio, cuyas líneas conducen a antepasados a los que primeramente se responsabiliza de deicidio, después de actitudes hostiles hacia la sociedad cristiana, y luego, tras la conversión, de apostatar. La imagen, pues, que divulgan es la de una casta y linaje que tiene origen "ex genere judeorum", y que precisamente por ese origen que los sucesivos eslabones generacionales mantienen y alimentan a través de la familia y el parentesco, continúa con sus creencias, con sus hábitos y con sus costumbres. Lo que hace diferente y falto de credibilidad al cristiano nuevo que busca la distinción - dentro de la sociedad a la que pertenece por derecho- aprovechando las oportunidades de movilidad que se registran a lo largo de los siglos XV y XVI. En contra del propósito de bastantes de éstos conversos, por más que lucharan por romper con su pasado, con la "culpa» de sus padres - como puede verse por ejemplo en el Breve Reprehensorium adversus quosdam fratres religiosos, escrito por el bachiller Pal$\mathrm{ma}^{37}$ - debía seguir influyendo en estimación del cristiano viejo la casta de sus antepasados, su ascendencia defectuosa por razones vinculadas especialmente a la religión.

\section{SOBRE MOVILIDAD SOCIAL DE LOS CONVERSOS: «QUE LOS DESCENDIENTES EX GENERE JUDEORUM SON DESASOSEGADOS, AYRADOS, AMBICIOSOS ${ }^{38}$}

Lo que a posteriori, una historiografía decidida a revisar el papel desempeñado por los conversos en la historia de España, ha mostrado como una actitud crítica ante los valores que la mayoría de los cristianos viejos adoptan ${ }^{39}$ y tras la que existe una alternativa «fundada en una precoz axiología burguesa» ${ }^{40}$, en cambio a una

36 CARrasco, Rafael: «<Pureté de sang > et paix civile en Nouvelle-Castile (XVe-XVIe siècle)», en $Q u^{\prime}$ 'un sang impur.. , Provence, 1997, p. 84.

37 En éste tratado, en su cuarto artículo, titulado Quod filius non ponietur propter peccatum patris nec e contra, se aduce para demostrar que las culpas del padre no deben recaer sobre el hijo, el pasaje de Ezequiel, 18, 20: «El hijo no cargará con las culpas del padre ni el padre con las del hijo» (GONZÁLVEZ, Ramón : «El bachiller Palma y su obra de polémica proconversa», en Qu'un sang..., p. 53.

38 Tratado donde se ponen.......,p. 141.

39 Así lo pone de manifiesto a través del estudio de la literatura conversa, entre otros, ALCALÁ, Angel: «El mundo de los conversos....», pp. 91-118. Opinión que igualmente comparten otros autores como GILman, Stephen: The Spain of the Fernando de Rojas. The intelectual and social landscape of $<$ La Celestina $>$, Pricenton, 1972.

40 Marquez Villanueva, Francisco: «Ensayo introductorio» a Domínguez Ortíz, Antonio: La clase social...... IX-XXVI. También GuTIERREZ NIETO, Juan Ignacio: «La estructura castizo.....», expone la posibilidad de los conversos de convertirse en la burguesía castellana. 
parte mayoritaria de la sociedad a lo largo de los siglos XV al XVII les pareció lo contrario y acabó calificando su actitud como «desestabilizadora».

Y no podía ser de otra manera si miramos la realidad desde el lado del cristiano viejo, que vio cómo no sacaba todos los beneficios que podía a una época en la que la movilidad, el desplazamiento hacia arriba, fue posible debido a las oportunidades que existían dentro de la sociedad estamental. Las posibilidades de ascenso social a los estados superiores que tuvieron los cristianos viejos no privilegiados, a partir de la segunda mitad del siglo XV, hubieron de compartirlas con cristianos nuevos provenientes de un linaje defectuoso. Así sucedió, ya que la situación de los últimos había cambiado completamente, pues aun con descendencia judía, con antecesores judíos, a diferencia de sus antepasados, ya no eran una casta, o para ser más precisos, como ha señalado L. Suárez Fernández ${ }^{41}$, una microsociedad segregada e inhabilitada para acceder al mundo de los honores. Las aguas bautismales no solo hacían al judío cristiano, sino que además le otorgaban derechos o privilegios según su status dentro de la sociedad de ordenes; ocurriendo, para desesperación del cristiano viejo, que quienes recibieron el sacramento, en su mayoría, fueron las elites sociales de las aljamas, dotadas de preparación intelectual en unos casos, y de riqueza en otros, por lo que no les resultó difícil en aquellos momentos de «ventilación social» el acceso a oficios públicos y a instituciones prestigiosas. Es un hecho bien conocido, pues por ejemplo conocemos como los Santamaría, los Maluenda y los Cartagena pasaron a ocupar cargos en el regimiento de Burgos, la familia Beltrán en Soria, la familia Lara en Murcia, o por no alargarnos y centrarnos en el más importante centro converso de Castilla: Toledo, los Herreras, los Francos, los Fuensalidas, los Moncadas, los Gutiérrez, o Zapatas también lo consiguieron ${ }^{42}$

La nueva situación no pasó inadvertida para buena parte de la sociedad. Un converso irreprochable -en opinión de Joseph Pérez ${ }^{43}$ - como fue Fernando del Pulgar (1435-1500) la describió, a la vez que refería como «insoportable» el ascenso de individuos de linaje judío para los cristianos viejos, de la siguiente forma:

«no podéis buenamente sofrir que algunos que juzgáis no ser de linaje tengan honras y oficios de gobernación... Asimesmo vos pesa ver riqueza en homes, que según vuestro pensamiento, no las merecen, en especial aquellos que nuevamente las ganaron» 44 .

41 SUÁREZ FERNÁNDEZ, Luis: Judíos españoles en la Edad Media, Madrid, 1980.

42 MARTZ, Linda: "Converso Families in Fixteenth and Sixteenth Century Toledo: The significance of lineage», Sefarad (Madrid), XIVIII (1988), pp. 117-196; y «Pure Blood Statutes in Sixteenth Century Toledo: Implementation as Opposed to Adoption», Sefarad (Madrid), LIV (1994), pp. 83-108.

43 PÉreZ, Joseph: Isabel y Fernando. Los Reyes Católicos, Madrid, 1988, p. 350.

44 PUlgar, Fernando del: Crónica de los Reyes Católicos, ed. Juan de la Mata, Madrid, 1943, p. 347.

Hispania, LXIV/2, núm. 217 (2004) 515-542 
En cambio, no solo la describen, sino que elaboran discursos hostiles contra tal proceso de movilidad, los partidarios del dominio o superioridad del cristiano viejo. Es el caso de un cronista de talante muy diferente, que confundía al judío con el converso ${ }^{45}$, como sucede con Andrés Bernáldez (1450-1513) en su Historia de los Reyes Católicos. Relata con gran malestar la promoción social de los cristianos nuevos, claramente de manifiesto, pues acceden a oficios con honra, cuentan con la confianza real y acuerdan estrategias matrimoniales con familias de linaje noble para afirmar su posición social.

Cabe preguntarse por qué quieren frenar este ascenso los cristianos viejos y estigmatizar socialmente al convertido por motivos de su origen. Los tratadistas de la limpieza de sangre apuntan como razones el número de los que han conseguido la promoción, su falta de adaptación al armónico funcionamiento de la sociedad y sus instituciones - piénsese por ejemplo el escándalo que representaba la conducta herética de algunos cristianos nuevos admitidos ${ }^{46}$-, y a su presencia organizada y con signos evidentes de bando-partido en las citadas instituciones.

Todo ello parecía quebrar el dominio del cristiano viejo sobre el mundo del honor y, con el fin de conservarlo, la mejor solución pasaba por establecer filtros, barreras, es decir, estatutos de limpieza. Con ellos se detendría el acceso de cristianos nuevos y se evitaría la presencia de individuos que actuaban movidos por actitudes («ánimos» dirán los tratadistas) evidentes de ascenso social - sin tener «virtudes» para ello-; a la vez que ponían en riesgo el pacífico funcionamiento del orden social.

En lo último que acabamos de señalar parece residir el freno que establecen los cristianos viejos a la movilidad de los nuevos. Temen que trastornen el orden social. Y esto choca de lleno con la idea que tienen quienes controlan su funcionamiento. Para ellos cada cual debe permanecer en su sitio, en su estado, permitiéndosele únicamente acciones que hagan más perfecto su estamento ${ }^{47}$. Junto a esto, también el propósito de cerrarles el paso a unos cristianos nuevos que quieren

«hazerse superiores, como lo procuran con todo conato en las repúblicas que tienen algún poder y mano, donde casi todos los escándalos y sediciones que ay. proceden de sus calumnias, inquieta condición y sobervios ánimos».

45 PÉREZ, Joseph: Historia de una tragedia. Expulsión de los judios de España, Barcelona, 1993, p. 80

46 En concreto en instituciones eclesiásticas, en más de un caso, se probó la herejía del cristiano nuevo. En la orden de los Jerónimos, en 1485, la Inquisición de Toledo quemó a Fray Diego de Marchena, monje de Guadalupe; poco después, en los años 1486 y 87, fueron llevados al quemadero otros cinco frailes de la misma orden procedentes del convento de Sisla. En Jaén fue relajado Juan Rodríguez de Alcaudete, párroco de la Iglesia de Santiago. Y en Murcia, por no extendernos mas, el año 1540 se exhumaron los restos del canónigo Juan de Santesteban y fueron quemados. Los ejemplos están tomados de DomínguEZ ORTIZ, Antonio: Los judeoconversos.... pp. 149-152; y HeRNÁNDEZ Franco, Juan: Cultura y limpieza de sangre en la España Moderna. Puritatis sanguinis, Murcia, 1996, pp. 46-56.

47 MARAVALl, José Antonio: Teatro y Literatura...., pp. 36-37. 
Por esta actitud que claramente señala una intención de ascenso, Bartolomé Ximénez Patón les echará en cara su inconformismo social, su insatisfacción para «vivir contentos en aquella parte que les ha tocado»" ${ }^{48}$, y con la que no están de acuerdo algunos de ellos, como ocurre por ejemplo con los financieros y los banqueros portugueses (que aspiraban a ocupar destacados puestos en la Corte y en sus instituciones, así como hábitos de órdenes militares tanto castellanas como portuguesas), que entre 1631 y 1641 permitieron a la corona y en especial a Olivares sostener la guerra con la que esperaba devolver la «Reputación» a la Monarquía Hispánica ${ }^{49}$ ¿Y cuál es esa parte dentro del orden social que le asignan los cristianos viejos? Según Alonso de Palencia (1423-1492), cuya opinión compartirán tratadistas posteriores, deben estar en los escalones más bajos de la sociedad, apartados del honor; en concreto se les considera como hombres de «baja extracción, acostumbrados a los más viles menesteres» ${ }^{50}$.

Dicho lugar debía ser frustrante para la parte más pudiente y activa de los cristianos nuevos, motivados en su conversión por el propósito de formar parte de los estados superiores y de acceder plenamente al mundo de honores que el cristiano viejo con poder o rango social había reservado, hasta entonces, para él. Esos intentos de asimilarse a la sociedad cristiano vieja, pero no de forma subordinada como deseaba el cristiano viejo, y su propósito de promoción social, explica que los estatutos pese al espíritu excluyente de su contenido, no desanimaran al cristiano nuevo y que a través de un amplio conjunto de estrategias (cambio de apellido, traslados geográficos, falsificación de genealogías, relaciones familiares con importantes familias cristianas viejas, e incluso relaciones clientelares con las mismas) intentara alejarse de un prototipo, de un retrato, de un modelo identitario -que como señala Marcel Proust, refiriéndose de forma genérica a las personalidades sociales, es creación de los otros- que les desligitimaba para su fin de acceder al mundo del honor.

Los resultados finalmente no parecen ser los que esperaban, pues prevaleció el modelo identitario que tomando como punto de partida el determinante principio del linaje, y agregando su desviado modo de vida, acabó arrinconando a muchos de los cristianos nuevos dentro de la sociedad castellana, o bien obligándolos a marchar fuera de España para rehacer su vida y sus expectativas (primero a Venecia, luego a Liorna, Ferrara, Bayona, Rouen....y finalmente a Amsterdam y Hamburgo) $)^{51}$.

48 XimÉnez Patón, Bartolomé: Discurso......, folio 2v.

49 EluIOTT, John H.: El Conde Duque de Olivares, Barcelona, 1990, p. 412; y BoYAJIAN, James C.: Portuguese bankers at the court of Spain, 1626-1650, New Brunswick, New Jersey, 1983, p. 71-132.

so Palencia, A. de: Crónica de Enrique IV, Vol. III, ed. de Paz y Meliá, p. 108. Citado por Domínguez ORTIZ, Antonio: Los judeoconversos en España y América, Madrid, 1971, pp. 23-24.

51 Remitimos para ésta cuestión a los trabajos de Yerushalmi, Yosef Hayim: De la Corte española al gueto italiano. Marranismo y judaísmo en la España del siglo XVII: el caso de Isaac Cardoso, Madrid, 1989; y KAPLAN, Yosef et al.: Diaspora Sefardí, Madrid, 1992. También son de interés los 
4. «ESTE LINAJE DE HOMBRES TIENE ESTAS MALAS CONDICIONES» O LA CONSTRUCCIÓN DE UNA IDENTIDAD CONTRA EL CRISTIANO NUEVO PARA APARTARLE DE LA SOCIEDAD DEL HONOR.

En el conflicto entre cristianos viejos y cristianos nuevos que se registra en Castilla durante los siglos XV-XVII, resulta frecuente encontrar en los escritos de los tratadistas próximos a los primeros una identidad autocomplaciente, autoestimativa, que les conduce al embelesamiento en sus valores y en la correspondiente ideología que los sustenta, que tiene como argumento central la «limpieza de su nacimiento y linaje» - y que obviamente no fue uniformente seguido por todos los veterocristianos ${ }^{52}$ - En cambio, cuando efectúan el retrato de los otros, de los cristianos recién convertidos, a los que tratan de vincular a la condición de "enemigos», ponen énfasis en la falta de calidades, de virtudes para formar parte de la sociedad del honor, debido a una conducta y a un modo de vida que enlaza con la de sus antepasados, la nación, raza ${ }^{53}$ o linaje judío, a través de la sangre — siempre viva, operante o afecta a sus orígenes-

apartados que dedica a la salida de sefarditas de la Península ALPERT, Michel: Criptojudaísmo e Inquisición en los siglos XVII y XVIII, Madrid, 2001, pp. 52-55.

52 Destacados personajes de la espiritualidad española fueron contrarios a los estatutos. Por citar solo algunos casos en la segunda mitad del siglo XVI: el padre Uceda, fray Antonio de Córdoba, fray Luís de León, fray Domingo de Valtanas; o, al menos, de poner límites a su aplicación, como ocurrió con el padre Salucio. Pero por encima de todos sobresalen los generales de la Compañía de Jesús, la orden más reformista del mundo católico, que antepuso la fe de sus miembros al descrédito que sobre ellos podía caer por no establecer estatuto de limpieza, como habían hecho la mayor parte de las ordenes religiosas, quizás con la única excepción de la de Santo Domingo (donde solo algunos conventos los estatuyeron a título particular), como ha señalado Dominguez ORTIZ, Antonio: Los judeoconversos, pp. 149-152). Como decimos, los primeros generales de la Compañía, es decir, Ignacio de Loyola (1541) -lo que le valió una agria polémica con Martínez Silíceo-, y sus sucesores: Francisco de Borja, Laínez, Polanco (vicario general) y Mercuriano no propusieron ni aprobaron estatuto. Sería ya el año 1592, cuando el general Acquaviva ordene que no se admita a los manchados.

No es una excepción el hecho de que la Compañía de Jesús no establezca estatuto de limpieza de sangre. Tampoco lo tuvieron otras instituciones de prestigio. Por ejemplo el cabildo de Salamanca después de aprobarlo lo revocó, y fracasaron totalmente quienes quisieron establecerlo en los cabildos de Burgos, Zamora y Tuy.

Por lo expuesto se puede deducir que es difícil medir el grado de aceptación y apoyo que tuvieron los estatutos de limpieza de sangre. Historiográficamente encontramos posturas como la de KAMEN, Henry: «Una crisis de conciencia en la Edad de Oro en España: Inquisición contra limpieza de sangre», Bulletin Hispanique (Burdeos), LXXXVIII, 3-4 (1986), pp. 321-335, que sugiere que muchos españoles (y no solo de origen judío) se opusieron a los estatutos. Totalmente opuesta y quizás más próxima a la realidad sea la de SICROFF, Albert: Los estatutos de limpieza..., pp. 9-24, que sustenta la obsesión por la limpieza de sangre que existió entre los castellanos, y el empleo de los estatutos por parte de las instituciones para purificarse frente a la presencia de conversos.

53 La utilización de fuentes elaboradas por la inteligencia "cristiano vieja» por nuestra parte para elaborar el presente trabajo, nos lleva a fijar la atención en lo que los autores de los escritos consideran sospechosas formas de vida del converso y en sus estrategias a la hora de ocupar un lugar de relieve dentro de la sociedad de ordenes. En cambio, aquellos otros investigadores que utilizan

Hispania, LXIV/2, núm. 217 (2004) 515-542 
Pero al cristiano viejo no le preocupa únicamente la «fuerza de la sangre» o la "afición de la sangre», que como señala Diego Simancas en su Defensio Statuti Toletani a sede apostolica saepè confirmati pro bis qui bonoEincontaminato genere nati sunt (1575) hace que un hombre que ha vivido como católico hasta los treinta años, al descubrir su ascendencia hebrea retorne a la religión de sus antepasados $^{54}$. Mucho más aún, y quizás sea el motivo de mayor peso para estigmatizar la imagen del converso, le inquieta la forma en cómo se está produciendo inicialmente el proceso de adscripción social del recientemente bautizado ${ }^{55}$. Esto ocurre debido a que «retiene» dentro de la sociedad de ordenes, según el tratadista nobiliario de fines del quinientos Juan Bautista de Guardiola, el status que poseía en la microsociedad de la que procedía ${ }^{56}$. Si a ello unimos, además, los procesos de mejora social, de «empinamiento" de algunos conversos como resaltaba el cura Bernáldez y que eran constatables, pues pasaron a formar parte del patriciado urbano de las ciudades castellanas y emparentaron con la nobleza, nos situamos ante el verdadero problema. Que no es otro, que la posibilidad de adscribirse a los escalones más altos del orden social, lo cual les otorgaba derechos y les identificaba socialmente, calificándolos como dignos para desempeñar funciones sociales (por lo general de mando e influencia) consideradas como distinguidas ${ }^{57}$ - aunque Libros Verdes y «linajudos», en los que se recordaba su origen, resultaran un freno considerable-.

Sucede, por consiguiente, que con el acceso de cristianos nuevos al orden social estamental, de naturaleza casi inelástica, especialmente en su escalas superiores, tiene lugar una dura competencia en torno a funciones u oficios que poseen honor y estima, y que a la vez sirven para ser identificados socialmente, para que se les reconozca una posición distinguida dentro de la sociedad. Hidalgos, patriciado urbano y cristianos viejos con preparación o riqueza, que habían tomado conciencia a partir del siglo XV del peso e influencia que adquirían los conversos ${ }^{58}$

preferentemente fuentes de cristianos nuevos disidentes, enfatizan sobre la conflictividad entre cristianos viejos y nuevos por razón de la raza, como ocurre con NETANYAHU, Benzion: Los orígenes de la Inquisición, Barcelona, 1999, y YerushalmI, Yosef Hayim: «L'Antisémitisme racial est-it apperu au XXème siècle? De la limpieza de sangre espagnole au razisme: continuités et ruptures», Esprit, 3-4 (1993), pp. 5-36.

54 SiCROFf, Albert: Los estatutos de limpieza...., p. 201.

55 Sigue siendo de alto interés para conocer la procedencia social del converso - alta - y los motivos de su bautismo — «carrerismo», exasperación por la discriminación que padecían los judíos, y convencimiento en algunos casos de que la verdadera fe era la cristiana-, los trabajos de BEINART, Haim: "The conversos and their fate», en KEDOURIE E. (ed.): Spain and the Jews, Londres, 1992, pp. 92-123; y MONSALvo ANTóN, José María: Teoría y evolución de un conflicto social. El antisemitismo en la Corona de Castilla en la Baja Edad Media, Madrid, 1985, pp. 277-296.

56 GUARDIOLA, Juan Benito: Tratado de nobleza y los títulos y dictados que oy tienen los varones claros $y$ grandes de España, Madrid, 1591, pp. 11-21.

57 Siguen teniendo total validez las afirmaciones hechas sobre la estructura y carácter de la sociedad estamental por Maravall, José Antonio: Poder, bonor....., pp. 20-32.

58. MONSAlvo ANTÓN, Jose María: Teoría y evolución...., pp. 277-296. 
y que estaban acostumbrados a que sus relaciones con los judíos estuviesen presididas por la desigualdad en el orden social y la subordinación en el orden políticos9, y tal como dice en los inicios del siglo XVII Baltasar Porreño (recogiendo a su vez la opinión contenida en discursos antijudíos y anticonversos elaborados a partir de 1470, como el Fortalitium fidei de fray Alonso de Espina) «siente(n) mal que los deszendientes de judíos sean lebantados a oficios y dignidades» ${ }^{60}$.

Para el cristiano viejo el nuevo ha cambiado de fe no por convicción, sino para vivir «mas gloriosamente» ${ }^{61}$, y encuentra pruebas evidentes en el continuo acceso a los oficios de instituciones sociales importantes; en principio reservados, como si de un monopolio se tratara, a los más «dignos» de los cristianos viejos. Y buena parte de estos veterocristianos, empezando por el sector nobiliario ${ }^{62}$, cuando toma conciencia de la presencia de cristianos nuevos en las instituciones que consideran bajo su influencia y control, es decir en los cabildos concejiles - por ejemplo en Toledo se ha verificado que un tercio de los regidores que desempeñan oficios a lo largo de los siglos XV al XVIII fueron conversos o tenían ese origen ${ }^{63}$-, en los cabildos eclesiásticos — también en el de Toledo, en la cuarta década del siglo XVI, el deán, el maestrescuela, el capiscol, el capellán mayor y cinco canónigos tenían origen converso-, en las ordenes religiosas, en las cofradías, en los colegios mayores... legislan para apartarlos. Pondrán todo su esfuerzo en tal exclusión, pues ocurre que esa presencia es activa, «rebolvedora» según los cristianos viejos, ya que actúan con sentido de grupo o bando, a lo que les impulsa sus relaciones de parentesco familiar, de amistad, de forma de vida ${ }^{64}$; en una palabra, el peso de su ascendencia, de su larga y común raíz, de su «título de linaje» en acertada expresión del franciscanos Uceda ${ }^{65}$, que sus antepasados han hecho todo lo posible por conservar, para reconocerse como pueblo o nación antes de la conversión, y que bastantes cris-

59 KRIEGEL, Maurice: Les juifs à la fin du Moyen Age dans l'Europe mediterranéenne, Paris, 1979, p. 13.

60 BNE, Ms. 13.043: «Defensa del estatuto de limpieza que fundó en la Sancta Iglesia de Toledo el Cardenal y Arzobispo Don Juan Martínez Siliceo compuesto por el Licenciado Balthasar Porreño cura de Sazedon, dirigido al Deán y Cabildo de la dicha Sancta Iglesia de Toledo, Madre y Primada de las Españas", MDCVIII, folio 9.

61 Ibid., folio 21. Como ocurre en la mayor parte de los argumentos que desarrolla Porreño para justificar el establecimiento de estatutos, previamente ya habían sido enunciados por el propio Siliceo en las causas o razones que expone al príncipe Felipe - a través del Consejo de Castilla - el año 1548 para lograr la confirmación del estatuto que ha establecido en la catedral de Toledo.

62 GUTIERREZ NIETO, Juan Ignacio «La estructura castizo-estamenta......», p. 553.

63 Si en el trabajo de MARQuez VillanueVa, Francisco: "Conversos y cargos concejiles en el siglo XV», Revista Archivos Bibliotecas Museos (Madrid), LXIII (1957), p. 503-540, ya quedó indicada la presencia de los conversos en los principales oficios públicos, los minuciosos trabajos de ARANDA PÉReZ, Francisco José: Poder y poderes en la ciudad de Toledo, Ciudad Real, 1999, pp. 254-263, y MARTZ, Linda «Pure Blood Statutes ....», pp. 83-108, lo cuantifican con mucho mayor detalle.

64 BNE, Ms. 6170, «Libro de las causas...», tercera parte relativa a los «méritos y calidades» de los que contradijeron el estatuto.

65 Tratado donde se ponen...., p. 75

Hispania, LXIV/2, núm. 217 (2004) 515-542 
tianos viejos o instituciones creadas o dirigidas por éstos van a volver contra los nuevamente bautizados.

La ley, la normativa, el estatuto a la postre, señala como fundamental e inexorable para la admisión en oficios el origen y el linaje, libres de cualquier mancha étnica. Por lo cual y según los proponentes de los estatutos, a los que ellos mismos llaman «estatutos de linaje», solo están cualificados para desempeñar cargos de honor los cristianos viejos. A su vez, los estatutos hacen posible el otro fin que se persigue con su aprobación, como es la «exclusión de los conversos», o lo que es lo mismo, cerrarles «totalmente las puertas a los conversos» dentro de la sociedad del honor según escribió el tratadista Bartolomé Ximénez Patón ${ }^{66}$.

Por tanto, y para cumplir estos fines, tal como destacan buena parte de los discursos y memoriales de limpieza de sangre que se escriben entre los siglos XV y XVII (por lo general en una línea de malestar social contra el cristiano nuevo por su actividad como financiero, o por la ocupación de oficios en instituciones importantes, como ocurre en Toledo en los críticos años de 1449 y 1547), se pone de relieve que los conversos provienen de un linaje que por su origen y conducta les inhabilita - solamente eso- para poder ingresar en oficios de instituciones de prestigio. Para probarlo, los autores más destacados: el bachiller Marcos García de Mora a mediados del siglo XV (como respuesta a la bula de Nicolás V, titulada Humani Genere Inimicis, de 24 de septiembre de 1449 , en la que reprueba la división entre cristianos viejos y cristianos nuevos), el arzobispo de Toledo Juan Martínez Silíceo y los miembros de su cabildo partidarios de establecer estatuto de limpieza el año 1547, así como Diego Simancas (1575) y Baltasar Porreño (1608) que justifican los argumentos de Silíceo, y Bartolomé Ximénez Patón (1638) uno de los principales defensores de los estatutos durante el siglo XVII, junto a Juan Escobar del Corro y fray Francisco Torrejoncillo, recurren a un amplio conjunto de hechos, sujetos a una interesada selección, mediante los que elaboran una identidad manipulada y desenfocada del otro $^{67}$. Precisamente esa otra identidad les convierte en «sospechosos», en un grupo perjudicial para el pacifico y armonioso funcionamiento de la sociedad de ordenes, debido a la conducta heredada y vivida por el cristiano nuevo, que es totalmente diferente al modelo identitario del hidalgo-cristiano viejo ${ }^{68}$.

66 Ximénez Patón, Bartolomé: Discurso....., folio 5 r.

67 Interesantes reflexiones sobre la construcción de estas identidades manipuladas, inicialmente proyectadas sobre el converso, y con posterioridad, posible germen de una identidad nacionalista, pueden encontrase en AZURMENDi, Mikel: $Y$ se limpie aquella tierra....., passim. También interesante para comprender la construcción del hecho identitario «raza vasca», que tiene como uno de sus pilares fundamentales la pureza de raza, el trabajo de ARANZADI, Juan: «Raza, linaje, familia y casasolar en el País Vasco», Hispania (Madrid), 209 (2001), pp. 879-206.

68 Sobre el modo de vida diferente del converso castellano, el «vivir» converso como lo llamó Américo Castro, repleto de rasgos burgueses y postulados críticos, resultan de enorme interés, respectivamente, los trabajos ya citados de MÁRQUEZ VILLANUEVA, Francisco «Ensayo introductorio» a Domínguez Ortíz, Antonio: La clase social..., IX-XXVI, y ALCALÁ, Angel: «El mundo de los con-

Hispania, LXIV/2, núm. 217 (2004) 515-542 
El recipiente que emplean estos autores proestatutarios para reunir y conectar los nocivos rasgos identitarios de los conversos, con frecuencia protagonizados por una pequeña parte del grupo o bien por individuos aislados (como ocurre en el caso de su participación en las Comunidades de Castilla) y en otros inventados (como posiblemente ocurriera con la crucifixión de un niño en La Guardia, Toledo, el Viernes Santo de un no datado año de la década de 1470), es el linaje de raíz étnico-religioso ${ }^{69}$. Este mantiene en activo su forma de vida a través de los antepasados, y a lo cual contribuye poderosamente la conciencia de familia y parentesco que poseen los judíos ${ }^{70}$ y heredan los conversos. De tal forma que el linaje se convierte en un conducto inmemorial, pero no de honor como ocurre entre quienes aspiran a inmaterializar su posición social entre los cristianos viejos, sino de infamia, de vileza, de ruindad, que generación a generación y alimentado por una sangre que nunca pierde su naturaleza inicial y de continuo determina la acción de los hombres de esa cultura o nación, va formando e induciendo su conducta, la conducta del «converso de linaje de judío». Buena prueba de ello, en opinión de fray Francisco Torrejoncillo (Centinela contra Judios, puesta en la Torre de la Iglesia de Dios, 1674), se encuentra en conversos separados de sus antecesores judíos por veintiuna generaciones y que han vuelto a judaizar ${ }^{71}$.

Los tratadistas para deslegitimar la identidad conversa recurren a argumentos empleados ya contra el judío en la Edad Media; aunque, obviamente, trasladados al converso y resituándolos en el momento histórico en que escriben. Recogerán una extendida opinión entre la cristiandad acerca del carácter dañino del pueblo hebreo, del que resulta heredero el converso mediante el silogismo «de que las cosas pasadas» presuponen las que «están por venir» ${ }^{72}$. De hecho, el judío y el converso para el común de los cristianos pertenecen a un linaje deicida, que arrastra una permanente «deuda de sangre»; esta es imbo-

versos....", pp. 91-118. Igualmente, y en el caso de los auténticos criptojudíos, hay que señalar —en opinión de KAPLAN, Yosef: Judios nuevos en Amsterdam...., pp. 27-28- una profunda identificación interior con la herencia religiosa judía.

69. Smith, Anthony D.: National Identity, Londres, 1991, ha puesto de relieve el papel de las etnias, antes de la aparición de las naciones, como medio para conservar la memoria de una comunidad; no es preciso una estructura política para crear una identidad a partir de la memoria, de los mitos y, por supuesto, de la raza.

Particularmente para el período tratado y los problemas citados, es decir, etnia y nación, resulta enormemente interesante el trabajo de CONTRERAS CONTRERAS, Jaime: «Historiar a los judíos de España: Un asunto de pueblo, nación y etnia», en MESTRE SANCHís, Antonio y GimÉNEZ LóPEZ , Enrique (eds.): Disidencias y exilios en la España Moderna, Alicante, 1997, pp. 117-144.

70 LANGE, Nicholas de: El judaísmo, pp. 25-28, y 121-126.

71 SICROFF, Albert: Los estatutos de limpieza......, pp. 202-205; y MECHOUlan, Henry: «Du racisme religieux de Torrejoncillo à l'antijudaïsme «eclairée» de Feijoo», Revue d'Études Juives (París), 154, (julio-diciembre 1995), pp. 363-385.

72 Dicho argumento es ampliamente desarrollado por Martínez Silíceo en el «Libro de las causas...», especialmente en la primera parte: «Las causas generales que an movido a nos el dicho cavildo a hazer el dicho estatuto». 
rrable, pues el propio pueblo judío con motivo de la crucifixión de Jesús había pronunciado ante Pilatos «que su sangre caiga sobre nosotros y nuestros hijos» ${ }^{73}$. Y, ciertamente, aquel hecho, que fue convertido en pecado social ${ }^{74}$, todavía se esgrimía como causa a finales del siglo XVI:

«los christianos descendientes de los hebreos no han de ser admittidos a la religión de los frailes menores por quanto traen origen de los que crucificaron al hijo de Dios, de cuya muerte son participantes todos los que después acá han perseverado en su perfidia e yncredulidad»75.

Esta remota e imperecedera mancha del deicidio que afrentaba al converso por herencia, había tomado aún más cuerpo en la Edad Media, en la que además se identificó positivamente al cristiano con la sangre de Cristo, que era clara, preciosa y limpia ${ }^{76}$. Contara con la compañía de otra serie de prejuicios anteriores pero actualizados, de forma que el problema «deste linaje de hombre que deszienden de judíos», es decir la cuestión conversa, quede bien atada a la «larga rayz» ${ }^{77}$ que lo engendró, y se pudiera poner de manifiesto la falta de semejanza con el perfecto modo de vida del cristiano viejo, a la vez que deslegitimarles en su afán por conseguir honores. En contra del cristiano nuevo se emplean reiteradamente argumentos de carácter político (traición: comenzando por el apoyo prestado por los judíos a los musulmanes el año 711 con motivo de la toma de ciudades tan importantes como Toledo, siguiendo con las revueltas urbanas protagonizadas en el siglo XV por conversos durante los reinados de Juan II, Enrique IV y los Reyes Católicos en la misma ciudad, hasta concluir con la participación de los últimos a favor de las Comunidades de Castilla en los inicios de la segunda década del quinientos); religiosos (perseveración en la ley de Moisés e incredulidad y, luego, tras la conversión, herejía ${ }^{78}$, conexión con

73. CARo BAROJA, Julio: Los judíos en la España Moderna y Contemporánea, Vol. I, Madrid, 1986, 177; también PÉREZ, Joseph : Historia de una tragedia..., p. 9.

74 DEDIEU, Jean Pierre: «PPecado original o pecado social? Reflexiones en torno a la constitución y a la definición del grupo judeo-converso en Castilla», Manuscrits (Barcelona), 10 (1992), pp. 61-76.

75 El citado texto, para ser contrargumentado, lo contiene el tratado del Padre Uceda, contrario al estatuto establecido por la Orden Menor de los Franciscanos el año 1583 [El tratado donde se ponen..... , p. 142]

76 BILLER, Piter: «Views of Jews from Paris around 1300. Christian or <scientific>?» en WOOD, Diana (ed.): Christianity and Judaism, Studies in Church History (Londrés), 29 (1992), pp. 205-207; y ALEXANDRE-BIDON, Danièle (ed.): Le pressoir mystique, Actes du Colloque de Recloses, Paris, 1990 (Citados por RUCQUOI, Adelaine: «Noblesse des conversos?» en Qu'un sang..., pp. 89-108).

77 Ximénez Patón, Bartolomé: Discurso....., folio $4 \mathrm{r}$.

78 En torno a la relación entre herejía y exclusión de los cargos u oficios de honor, resulta de gran interés el trabajo de DeDieu, Jean Pierre: «Hérésie et pureté de sang: l'incapacité légale des heretiques et leurs descendants en Espagne au temps de l'Inquisition» en Pouvoirs et société dans IEspagne moderne : travaux / réunis par Jean-Pierre Amalric avec le concours du GDR 30 du CNRS, Toulouse, 1993, pp. 161-176.

Hispania, LXIV/2, núm. 217 (2004) 515-542 
el luteranismo ${ }^{79}$, participación en el movimiento o «secta» de los alumbrados, simulación ${ }^{80}$, profanaciones, crímenes rituales..., lo que supone -según estimaciones de los tratadistas- que casi 50.000 conversos sean procesados por la Inquisición a lo largo de la primera mitad del siglo XVI); psicológicos (asustadizos, cobardes, astutos, avariciosos, sutiles, soberbios, vanagloriosos, envidiosos, mentirosos, vengativos, sanguíneos...) ${ }^{81}$; y, en menor medida, económicos (logros y usura). Todos estos prejuicios desacreditan su forma de vida y su trayectoria como propia de un grupo con honor y, en cambio, la presenta como propia de un linaje de hombres - como los judíos - de «malas condiciones» ${ }^{82}$.

De esta manera, como un linaje de condición espuria y depravado por actos propios o de sus antepasados, se tiene a los conversos por parte de los tratadistas partidarios de la limpieza de sangre. La imagen pervertida del contrario la reconocen y definen en individuos concretos del linaje, a los que quieren hacer símbolo de todos los conversos, como ocurre a mediados del siglo XV por parte de Marcos García de Mora con el «bilisimo por linaje» Mose Hamomo -que no es otro que el relator del Consejo de Castilla Fernán Díaz de Toledo, converso $^{83}$ - y con los diez contradictores al estatuto del cabildo catedral de Toledo por parte de Silíceo y sus partidarios, de quienes estos «presume(n) que siempre fueron judíos aunque disimulasen ser xptianos»; o bien al grupo en su totalidad, ya que de forma colectiva son «generación de confesos y deszendientes del linaje y casta de judíos».

Expuestos los argumentos y creada la imagen, con la que son partícipes una amplia mayoría que desean que a las instituciones, sea cual sea su rango, accedan exclusivamente cristianos viejos ${ }^{84}$, finalmente realizan las acusaciones que

79 En torno a esta supuesta alianza entre luteranismo y judaísmo, que en realidad se debe a que ambos amenazan la unidad religiosa que pretende la Monarquía Hispánica, resultan de enorme interés los trabajos de REDONDO, Agustín «Luther et l'Espagne de 1520 à 1536» en Mélanges de la Casa de Velázquez (Madrid), I (1965), pp. 109-165; y BENASSAR, Bartolomé: Inquisición española: poder político y control social, Barcelona, 1981, pp. 231-237.

80 Sobre la tibieza y simulación del converso castellano son de enorme interés los trabajos de Orfali, Moisés: Los conversos españoles en la literatura rabínica. Problemas jurídicos y opiniones legales durante los siglos XII-XVI, Salamanca, 1982, donde examina la idea de que el converso «aunque pecó, Israel es», y tiene una puerta abierta para retornar al judaísmo; también DíAz EsTEBAN, Francisco: «La expulsión y la justificación de la conversión simulada», Sefarad (Madrid), LVI/2 (1996), pp. 251-263, que pone de manifiesto la actitud de los sefardíes, más proclives que los askenazíes al disimulo y a la apostasía.

81 Prácticamente hay unanimidad con los rasgos psicológicos señalados por parte de CARO BAROjA, Julio: Los judíos....., Vol. I, pp. 104-108; y de Monsalvo Antón, José María: Teoría y evolución....., pp. 107-134.

82 BNE, Ms. 6170: «Libro de las causas...», segunda parte: "Autoridades así de la Sagrada Scriptura como de los Sacros Cánones y algunas sentenzias de doctores y otras razones por las quales evidentemente se puede colegir y ynferir el dicho statuto si es santo y conforme a razon».

83 El Memorial de «Marquillos», reproducido por BENITO RUANO, Eloy: Los orígenes...., p. 105.

84 Por ejemplo, al mismo tiempo que Silíceo argumenta a favor de establecer estatuto de limpieza en el Cabildo de Toledo, en la misma ciudad y en el mismo año, es decir 1548, el procurador 
les cierran el paso a «vivir mas gloriosamente». Primeramente, siglos XV-XVI, se dirá que no es un linaje o grupo con un honor estimable, digno (infames, inhábiles, incapaces e indignos se les considera en la Sentencia-Estatuto del ayuntamiento de Toledo ${ }^{85}$ ) para compartir con ellos los oficios en instituciones de prestigio ${ }^{86}$. Y, posteriormente, a partir de la segunda mitad del siglo XVI y hasta por lo menos otro siglo y cuarto después, junto a la anterior inculpación, otra aún mayor; coincidirá con el «endurecimiento» de la política monárquica a partir de los últimos años del reinado de Carlos $\mathrm{V}$ respecto a los disidentes religiosos y especialmente respecto a los conversos bajo presunción ${ }^{87}$ - políticamente conceptuados como unos súbditos rebeldes-; se estimará que no eran seguros («sospechosos» de herejía) en la importante función que corresponde a todo buen ciudadano — por supuesto su contraimagen es el converso ${ }^{88}$ - de garantizar el ordenado y pacífico funcionamiento de la ante todo cristiana sociedad de ordenes, debido a su supuesta inobediencia en lo concerniente a las leyes religiosas y civiles que ha establecido la Monarquía Hispánica.

\section{CONCLUSIONES}

En realidad, lo que pretenden en Castilla los cristianos viejos respecto a los cristianos nuevo no es expulsarles de la sociedad de ordenes, de forma similar a como se extraña del Reino a los judíos. Su propósito se centra en lograr un rango de distinción, de reconocimiento social, de ventaja social para su permanente condición de veterocristianos, es decir para una trayectoria familiar caracterizada por una interrumpida pertenencia a un modo de vida siempre cristiano,

del Santo Oficio, Pedro Ortiz, escribe un amplio memorial en el que sostiene que el «delito del padre (se refiere al converso que ha regresado a su fe) acompaña al hijo y al nieto y le suceden en aquella sangre reprobada», por lo cual no deben ser «recebidos a honores algunos». Dicho memorial lo recoge íntegramente y lo analiza Rafael Carrasco, "<Pureté de sang >....», pp. 83-85:

85 El texto de la Sentencia-Estatuto del concejo de Toledo lo reproduce Benito RuANO, Eloy: Toledo en el siglo XV, Madrid, 1961, pp. 191-196.

86 Juan Martínez Silíceo y los partidarios de establecer estatuto en el cabildo toledano, exponen en el «Libro de las causas...»: "que los xptianos viejos no quieren tener compañia con los que deszienden de judios, pues en ellos se hallan las malas mañas y propiedades que Xpto nuestro señor y San Pablo dizen de ellos» (BNE, Ms. 6170).

87 Domínguez Ortiz, Antonio: Los judeoconversos....., p. 57.

88 Es de gran interés el contraste entre la imagen del «buen republico» que presenta el año 1611 Agustín de Rojas Villandrado, preocupado en conservar la paz y unidad espiritual de la sociedad y en ser un buen cristiano (véase IÑURRITEGUI RoDRíGUEZ, José María: La Gracia y la República, Madrid, 1998, p. 21), y la del cristiano nuevo que nos describe dos décadas después el tratadista Bartolomé Ximénez Patón. En su Discurso escribirá «que en lo corporal y exterior no aparezcan unánimes, estando en el espíritu diversos, fingiendo ser en lo aparente christianos, y en lo interior observando los ritos y ceremonias del judaísmo y de otras malas setas (sic), como lo hazen los infectos deszendientes dellas, reasumiendo las costumbres de sus progenitores».

Hispania, LXIV/2, núm. 217 (2004) 515-542 
por un existir y ser cristiano desde la determinante raíz u origen — que a la postre se convierte en una sustancia eterna-. Les preocupa conseguir ese fin a partir del siglo XV, cuando un grupo de individuos provenientes de otra raíz cultural y al que consideran integrantes de un linaje-nación (que ha mantenido vivo en la diáspora sus costumbres y su memoria a traves de las relaciones y vivencias familiares) hasta entonces socialmente marginado, se bautizan y tienen acceso a la cristianizada sociedad de ordenes. Dentro de la cual no se asimilan de un modo subordinado, sino que desarrollan un modo de vida que es diferente al del cristiano viejo por cuanto conserva algunos elementos de su cultura de procedencia, desarrollan otros propios de una axiología burguesa y, además, algunos aspiran y consiguen ingresar en instituciones sociales de prestigio, hasta esos momentos reservadas a la elite cristiana vieja.

De todos modos es conveniente insistir en que no es solo la herencia familiar, aunque esta aparezca como el argumento teórico más importante - y que además no se circunscribió al escalón de los intelectuales escolásticos, de los humanistas tardíos y de buena parte de los hombres de letras del Barroco, pues dispuso también de una amplia repercusión y aceptabilidad entre las capas bajas de la sociedad-, la que actúa como prejuicio desfavorable contra las familias cristianas nuevas. Así mismo, y como no podía ser de otra manera, existe relación con los sucesivos períodos culturales en los que se va desarrollando el problema converso; es decir, el Renacimiento y el Barroco, pues sus valores y normas, inciden directamente. Por lo que respecta al primero, era difícil en una Castilla menos influenciada por el humanismo de lo que ha supuesto la historiografía hasta fechas recientes, que el individualismo apoyado en una fuerza y actividad que hacía merecedor del éxito o virtú, pudiera corroer los aún sólidos argumentos de una cosmogonía cristiana y una sociedad dominada por los privilegiados, capaz tan sólo de admitir el medro de quienes se identificasen con las virtudes teologales y el honor nobiliario. Esto explica que las primeras generaciones - por obligación- de conversos castellanos (finales del siglo XV-primera mitad del siglo XVI) fracasaran desde la adopción del papel de hombres nuevos, de hombres que creían en su propia capacidad, y para ello no dudaron en emplear la riqueza en el propósito de alcanzar un importante papel social y político. Por eso, en este primer forcejeo por ocupar un espacio social influyente, como no, por parte del cristiano viejo se recordará la sangre manchada y defectuosa de los linajes cristianos nuevos; en la contraofensiva contra los últimos también participa la Inquisición, que no sólo rastreó las impurezas de esos linajes, sino que igualmente aliada con los bandos urbanos que se fueron constituyendo en bastantes ciudades castellanas, los acusó de herejía; la fortuna, pues, no estuvo de lado del converso en una etapa de plena efervescencia de la ortodoxia en el mundo católico y del comienzo del cierre de los bandos políticos que tradicionalmente habían dominado los regimientos castellanos.

Y la misma situación de apartamiento, de marginación en el terreno de la política y de las esferas de influencia, se vuelve a repetir cuarenta años después.

Hispania, LXIV/2, núm. 217 (2004) 515-542 
Entonces es cuando, como escribió J. A. Maravall, el cristiano viejo que vive o desarrolla las esencias del Barroco y sus directrices conservadoras, a lo largo de la primera media centuria del Seiscientos, rechaza la presencia (por más necesarios que resultaran a causa de los problemas financieros de la Monarquía Hispánica) de los hombres de la «nación» portuguesa. Es decir, de un grupo de descendientes de los judíos expulsados de Castilla en 1492 e instalados a continuación en Portugal, dónde también se les obligó a convertirse, y que eran expertos tanto en comercio como en finanzas; pero que a cambio de sus servicios a la Corona, en el caso de los de mayor fortuna, reclamaron prestigio social e influencia cortesana - logros que obtuvieron parcialmente durante el valimiento de Olivares (1623-1643), espléndidamente analizado por J. Elliott-.

Frente a estas dos extensas generaciones de conversos, movidos frecuentemente por las ansias de promoción social, de riqueza, de inserción normalizada dentro de la sociedad castellana, y entre los que probablemente hubo tantos falsos conversos (amusim) como verdaderos convertidos (misumad), y otra porción de vacilantes, a caballo entre la religión católica y la ley de Moisés, se alzó un elemento de control (no infranqueable, a veces demasiado poroso a causa del soborno para fabricar limpias genealogías familiares) como fueron las pruebas de limpieza de sangre. Para detener la incorporación de los cristianos nuevos a instituciones, especialmente a las más distinguidas, o bien para que su posición económica no les hiciese influyentes en la corte y les permitiera acceder a mercedes reales, como eran los hábitos de Ordenes Militares, los cristianos viejos intentaron convertir en ley positiva, a la vez que en virtú o gloria, su linaje limpio de mancha étnica, su linaje siempre vinculado a un modo de vida cristiano; de igual forma que la nobleza había conseguido su destacada posición a partir de un antiguo y esclarecido principio y un ethos propio.

$\mathrm{Y}$, al mismo tiempo, como contrapeso que destaca, distingue y diferencia su condición social, los cristianos viejos elaboran un discurso contra la identidad del otro, contra el enemigo converso. Junto a la raza, encuentra uno de sus fundamentos principales en el mito antihebreo de la sangre manchada o defectuosa a consecuencia del deicidio, transmitida a los nuevos cristianos por sus antepasados judíos. Todo lo cual aporta a las familias conversas una determinante herencia cultural que se manifiesta mediante una forma de existir y creer diferente a la conducta religiosa y civil (herejes y traidores) que es propia de los cristianos viejos. Por esa herencia latente («esta le está clamoreando en sus oydos y coraçones» dirá Bartolomé Ximénez Patón, opinión que ya habían señalado anteriormente algunos miembros de la última y represora fase del humanismo castellano, o bien la «inteligencia barroca», como ocurre con el gran literato Francisco de Quevedo, el poeta Huertas, y el diarista Pellicer), dispuesta siempre a manifestarse y hacerles reasumir sus orígenes, o por lo menos a desviarlos del modo de vida común a los cristianos viejos, leales a la Monarquía, a la verdadera Iglesia Católica y partidarios de conservar el orden social existente -netamente influenciado por valores nobiliarios-, en opinión de los 
veterocristianos hay que inhabilitarles para acceder a la sociedad del honor y ocupar funciones que consideran que exclusivamente les corresponden a ellos.

Por tanto, parece fuera de toda duda, que la sangre limpia fue un elemento castizo, vivido y representado como un valor positivo, al que se le hizo participar en la configuración social existente en Castilla durante los siglos XV al XVII. No fue un factor que adscribió a un status, o que lo otorgara, cuestión que continuó haciendo posible la condición noble o no de los antepasados, o bien la determinante gracia real en los casos de nuevos ennoblecimientos.

Sin embargo, el acceso a buena parte de las funciones sociales con honor, estrechamente conectadas y reservadas a los estados sociales superiores, se concedieron legalmente, tras demostrar, en la mayor parte de los casos, la pureza de sangre por ambas líneas familiares (lo cual no significa que no se falsificaran genealogías, o que desesperaran por falta de limpieza de alguna línea de su estirpe familias de la Grandeza castellana, como los Osorio, sobre los que siempre pendía - como demostró J. Caro Baroja - la inquietud de que se les recordara su parentesco lejano con Pablo de Santamaría, famoso rabino [Salomo Halevi] que en la centuria del cuatrocientos sería arzobispo de Burgos). Y esa limpieza, indiscutible valor social en la España de la cultura de las tres religiones, se convirtió en un privilegio para los cristianos viejos. En cambio, su falta hizo indigno al cristiano nuevo para acceder a distinciones, pues aun poseyendo el derecho como miembro de la sociedad de ordenes, estaba socialmente deslegitimado para acceder a plazas en instituciones con estima y relieve $y$, de hecho muchos fueron apartados, debido a la credibilidad social que adquirió la desenfocada imagen que proporcionaba la herencia de sus antepasados judíos y la reciente memoria y conducta del linaje-nación tras la mudanza de dogma.

Para el cristiano viejo, embriagado en su limpieza y en la ortodoxia de su $\mathrm{fe}$, y en otros casos además en su preparación intelectual, estuvo dispuesto y luchó durante los primeros siglos de la modernidad por convertir en un rango de distinción su linaje y sus valores, símbolos públicos exclusivos de ellos; frente a unos rivales, los otros, adscritos a su propia sociedad de órdenes, pero no aceptados por su origen y cultura, a los que siempre calificaron con la infamia que suponía ser conversos del linaje de judíos. 